\title{
Frames of silence: Some descriptions of the sounds of Antarctica
}

\author{
Stephen Martin
}

People sometimes say that when watching and listening in the great silences of Antarctica, they can hear their own heartbeat. Almost paradoxically, the great silences can be the frame for a discussion of the sounds and noises of the southern continent.

Before delving into this topic it may be useful to put the listening experience into a broader context of human experience in Antarctica and its surrounding seas.

When people go south they go with an extraordinary range of feelings and expectations. They come from a culture dense with meanings, understandings, symbols and relationships that are so familiar many of them are almost unconscious or even unrecognised.

This was brought into relief as I recently travelled through Bhutan, where the human culture and geography and nature are so intertwined that it's confusing - almost overload. The contrast with a trip to Antarctica - even with 200 years of human history and such understandings as we derive from modern myth and scientific understanding - is enormous. I remember standing in a rhododendron forest with reds, yellows and creams on the trees and thinking about tales of demons and yetis and yak herders that are set in such a forest and thinking just how young are our stories of the human presence in Antarctica.

So, as you travel south you experience a moving away from the density and complexity of human culture - if by sea, you will also get physically unwell and unsettled. You move into cold - sea birds, albatross, petrels and gulls follow the ship and eventually leave. You may see whales but you will see ice - in the form of bergs and large and small pieces floating in the water, and then you'll get to the continent. The air is clearer, you can see farther. More importantly for this discussion, you can hear from greater distances - the silences are enormous and overwhelming and the sounds travels farther in the clearer, dryer air.

And perspectives change - things seem out of kilter.

1 Stephen Martin, 8/4 Darley St East, Mona Vale NSW 2103, stephen.martin5@bigpond.com. 
For the most part you will lose the familiarity of the everyday. You won't see houses, streets, planes crossing the sky, other people as anonymous crowds. The noises we take for granted are gone.

It can be very unsettling. And into this sense of change and sensory confusion tumble the sights and smells and sounds of one of the world's most extraordinary places. You see blocks of ice that defy imagination - if at Commonwealth Bay or elsewhere, you'll see cliffs of ice hundreds of metres high. The water may be discoloured by ice or by plankton. Mountain-tops poking out of ice will be shrouded by mists, or nearly surrounded by glacier flows. The lights can at times be blinding, or subtly gloomy, a sort of light that makes the ice colours glow. In some places, the sun will set and rise again in 20 minutes - before disbelieving eyes.

It is different to everyday experiences of our northern homelands and some would now say magically so. Early visitors recorded their fear and horror, modern visitors a sense of awe and unreality.

But there are cycles and rhythms as well, seasonal cycles, cycles of light and dark, freezing and melting, a slow irregular rhythm of the glacier flow to the sea, the generation of icebergs as they calve and float slowly north.

So it is clear from this that the sounds can be quiet and ephemeral but they, like the natural noises around the planet, are also elemental and awe-inspiring.

Within this new and changing personal response, are the new sensory experiences - the sounds and noises and silences of Antarctica are experienced with fresh insights - possibly even meanings.

Composer Kyle Gann wrote about John Cage's work 4'33", a work of silence nearly 60 years old. Gann defines this work as:

An act of framing, of enclosing environmental and unintended sounds in a moment of attention in order to open the mind to the fact that all sounds are music ... It begged for a new approach to listening, ... a blurring of the conventional boundaries between art and life. ${ }^{2}$

The content of the composition is meant to be perceived as the sounds of the environment that the listeners hear while it is performed. The silences highlight the range of sound in the everyday environments.

It's a bit like a form of bearing witness, a Quaker prayer meeting, a communal act of respect and listening.

2 Kyle Gann (2010) No such thing as silence: John Cage's 4'33", Yale University Press, p. 42. 
I think it has some wonderful resonances for the human experience in Antarctica. And it's a direct link to Antarctic sounds, for the silences, experienced both individually and as a group, as respectful or even awed, are a common human experience in Antarctica - a silence that accentuates the other noises, the silence in which you can hear/feel your own heartbeat.

Here's a list of some of the typical sounds of Antarctica. The sea - washing against the ice, crashing into large icebergs, yes, even gently lapping the shores; the ice (obviously a wide range), sounds of the sea-ice bumping into each other - described by one 19th-century observer as the sounds of crepitation! broken bones rubbing against each other, sea ice cracking under foot (be aware!). The strange and wonderful boom or crack of a glacier cracking — on a still day this noise reverberates through hills - sometimes it is difficult to tell where it comes from and that is a little unsettling; the wind - in the rigging, around huts, across the plateau, the gentle whistle of the wind in the bits and pieces of your clothes; the animals, whales blowing, birds calling, fur seals now repopulating the Peninsula, and penguins. We hear of one of the most unusual sound relationships - that of people, visitors and penguins.

We have great fun with the penguins - especially making them dance by singing to them. ${ }^{3}$

And of course, people, including noises from talk, radio, ships, recorded music, singing, chattering and celebrations.

There is a strong, almost religious connotation to the descriptions of this silence and an accompanying sense of intrusion - of not quite belonging — which is appropriate for the levels of human occupation in Antarctic. Other sounds mark these occupations of the continent and the technologies people used in attempting to assess the meanings of the sounds or silences.

The silences are a leitmotif, a characteristic of the environment that is a reminder of people's unease and unfamiliarity in Antarctica. Sometimes it's more than this, an intimation of intrusion.

So how do these references appear in the diaries of people who go to Antarctica? They appear described directly and sometimes by implication. Interestingly, sounds and noises and music are not much described in the journals and diaries I've looked at. Obviously the recording of sounds was not a first priority for these diarists.

3 Apsley Cherry-Garrard in Stephen Martin (1996) A history of Antarctica, State Library New South Wales Press, Sydney, p. 136. 


\section{Some examples}

In 1929, United States expedition leader Richard Byrd flew over the south. He soberly described the regions around the pole as a 'white desolation and solitude'; his pilot Berndt Balchen was more introspective:

I was glad to leave. Somehow our very purpose here seemed insignificant, a symbol of man's vanity, an intrusion on this eternal white world. The sound of our engines profaned the silence as we headed back to Little America. ${ }^{4}$

In 1939 Byrd returned to lead another expedition at 'Little America' on the Ross Ice Shelf. This time the men had a radio setup and sent broadcasts out into the world. Byrd had misgivings, like those he expressed when he first heard morse code messages being tapped out for the first Little America broadcasts. He noted,

When too much talk seems to be the cause of much of the grief in the world, no man could break the isolation of the Last Continent of Silence without a twinge of remorse. ${ }^{5}$

Byrd established a small base a few miles inland from Little America and lived there for a few months. Alone in the Antarctic winter, Byrd took the opportunity to reflect. One afternoon he 'paused to listen to the silence ... the imponderable forces of the cosmos functioning gently, harmoniously, soundlessly ... This is the way the world will look when it dies'.

In the 1930s John Rymill and his team were in the Peninsula. John Stevenson and others looked south into new territory:

Everywhere was complete calm silence; the sound from the other tent ... we were further south than anybody else in the world, and apart from our companions at the base, there was no human being within 1,500 miles. It made one feel extremely insignificant to see and think of such vast areas untouched by man, and in which man had had no influence whatsoever. ${ }^{6}$

Incidentally, soon after this he listened to political radio broadcasts from Europe, so the silences and noises were then and are now tempered by contact with home.

Bernt Balchen and Richard Byrd in Stephen Martin (1996) A history of Antarctica, p. 179.

5 Richard Byrd in Stephen Martin (1996) A history of Antarctica, p. 40.

6 John Stevenson in Stephen Martin (1996) A history of Antarctica, p. 54. 
Edward Wilson, with Robert Falcon Scott's second expedition (1910-13), wrote a report for the expedition publication. The report was of an arduous and sometimes terrifying journey undertaken to Cape Crozier in the late winter. Despite the conditions the men survived the experience. As befits such a report, it is written in a clear style but there are some engaging descriptions and references to the noises and sounds. They may appear strange, but they became a part of the common experience for Wilson and his companions.

Here are the sounds of Antarctic routines, of the surrounding environment, sometimes familiar, often as locators in the new world, sometimes frightening, threatening or dangerous.

Tuesday June 27, '11 We camped for lunch at $2.30 \mathrm{pm}$. having made $6 \frac{1}{3}$ miles from Cape Evans. The double tent was easy to pitch, and we began a routine of brushing down the inside, after removing all the contents, every time we broke camp. This routine we continued the whole way to Cape Crozier and it made a great difference to the collection of ice on the upper two-thirds of the tent.

Standing on or near the pressure ridges of ice sheets and learning to read these noises brought the men to a fuller understanding of the world around them.

Sunday July 9, '11 These were obviously the pressure ridges, and when we stood still we could hear a creaking and groaning of the ice underneath and around us, which convinced us, and later led us to think that the tidal action of the coast here was taken up in part by the pressure ridges without forming any definite tide crack

and

Monday July 10, '11 By noon a blizzard was blowing from the S.SW of force 6 to 8 and the air was as thick as could be with snow. This continued all day and we lay wet and warm in our bags listening to the periodic movement of the ice pressure, apparently tidal to some extent, beneath and about us.

Travelling in these lands was a new experience and one sometimes interrupted by strange new sounds.

Wednesday July 19, '11 We had about a mile to go down snow slopes to the edge of the first pressure ridge, and our intention was to keep close in under the land ice cliffs which are very much more extensive now than they were ten years ago. Then we hoped to get in under the actual rock cliffs which had always been the best way down to the rookery in the Discovery days. But somehow we got down by a slope which led us into a valley between the two first pressure ridges, and we found it 
impossible to get back in under the land ice cliffs. Nor had we then seen any other way down from the land ice except by the slope we followed. The rest was apparently all ice cliff about 80 to $100 \mathrm{ft}$ high. We tried again \& again to work our way in to the left where the land ice cliffs joined the rock cliffs but though we made considerable headway now \& then along snow slopes and drift ridges by crossing the least tumbled parts of the intervening pressure lines, we yet came time after time to impossible places \& had to turn back \& try another way. We tried one possible opening after another and all led to further impasses until the daylight was two-thirds gone and we found ourselves faced in a large snow hollow by a chaotic pile of ice blocks \& snow drifts standing almost vertically in our path and all round us to a height of some $60 \mathrm{ft}$. and completely stopping all chance of progress forward. Here we had the mortification of hearing the cries of Emperor Penguins echoed to us by the rock cliffs on our left. We were still however out of sight of the rookery and we had still a quarter of a mile of chaotic pressure to cross, so we reluctantly gave up the attempt for the day and with great caution and much difficulty owing to the failing light retraced the steps it had taken us about three hours to make. We had been roped together the whole time and had used the sledge continually over soft and rotten looking snow bridges. It was dark by the time we reached safe ground after clambering about 5 hours to no purpose.

And they experienced severe storms. The men had set up a tent and attempted to sit out a fierce storm.

Sunday July 23, '11 The roof went as follows. We saw, as soon as light showed through the canvas in the early morning, that the snow blocks on the top had all been blown off, and that the upward strain was now as bad as ever, with a greater tendency to flap at the lee end wall. And where the canvas was fixed in over the door it began to work on the heavy stones which held it down, jerking and shaking them so that it threatened to throw them down. Bowers was trying all he could to jam them tight with pyjama jackets \& bamboos, and in this I was helping him when the canvas suddenly ripped, and in a moment I saw about six rents all along the lee wall top \& in another moment we were under the open sky with the greater part of the roof flapped to shreds. The noise was terrific, and rocks began to tumble in off the walls on to Bowers \& Cherry, happily without hurting them, and then the sledge fell in across our sleeping bags, and in a smother of drift Bowers \& I bolted in to our own bags, and in them the three of us lay listening to the flap of the ragged ends of canvas over our heads which sounded like a volley of pistol shots going on for hour after hour. 
They survived this and continued on, the weird new sounds again reminding them of a new and unfamiliar geography.

Saturday July 29, '11 We got away before daylight and marched a good soft plod all day, making $6 \frac{1}{2}$ miles. Subsidences were frequent and at lunch the whole tent and contents, myself included as I was cook for the day, dropped suddenly with a perceptible bump, and with so long and loud a reverberation all round that we all stood \& listened for some minutes. Cherry said it started when his foot went through some snow under the top crust, not when he was digging through this crust. The central subsidence set off innumerable others all round \& these others in continually widening circles \& the noise took quite some two or three minutes to die away. ${ }^{7}$

Here are some of the human noises and associations noted in the diaries of George Dovers of the Australasian Antarctic Expedition 1911-14. As the expedition vessel, the Aurora, approached the continent:

My first impression, a cry of land on the starboard, away up we all clattered, a light snow was falling, on the port the magnificent ice barrier with the ice blink reflected over it, giant bergs lying grand and splendid between us and the as yet almost invisible land and there looming through the snow on our starboard and ahead the indistinct form of land, which gradually resolved into a sheer ice cliff a vast line with snow and ice covered slopes running back inland and some spires approx. 3 or 4,000 ft high, I will never forget the first sight, it looks very rugged and we may have some difficulty landing. ${ }^{8}$

Here the descriptions of human sounds in Antarctica take on a sense of community - of a small number of people in a strange land, a bit like Dover's description of people smoking in a cabin of the Aurora.

They call our cabin [on Aurora] the smoking room after meals we all get in there and the place fairly reeks, now and then a face looms through the smoke and you can tell where a fellow is by the sound of his voice. ${ }^{9}$

One of those diarists who wrote evocatively about a sledging journey was Frank Hurley with the Australasian Antarctic Expedition. Often seen more as a photographer than as a writer, Hurley wrote engagingly about life in Antarctica. Hurley was with Bob Bage and Eric Webb on a sledging journey south towards the south magnetic pole in 1912-13.

7 Edward Wilson (2011) A tale for our generation: an account of the winter journey. Australian Capital Equity, West Perth.

8 George Dovers, Australasian Antarctic Expedition Mitchell Library, Sydney, MLMSS 3812, p. 14.

9 George Dovers, Australasian Antarctic Expedition Mitchell Library, Sydney, MLMSS 3812, p. 16. 
12 November [1912]. The blizzard raged throughout the night and this morning little alteration has taken place. In our tiny tent we can barely move about, while to converse with one another we have to raise our voices to a shout so terrific is the swish of drift in the blizzard din.

16 November. At 6:30 pm heavy nimbus clouds came rolling up from the south and we are wondering if it is again going to snow and blow. A halt was made and tents were erected in a dead calm! What a striking contrast to the blizzard's eternal roar. Every sound seems frozen. Our voices seem strange in this awesome silence, whilst our ears, so accustomed to continuous din, ache. What a stagnant silence! Our tent is limp, for not the gentlest Zephyr stirs. What is going to happen. Bob has just ordered our supports to throw snow on to the tent to make some noise so that we can go to sleep. What a place of excesses, and how welcome to us, wind battered toilers this cessation comes.

After leaving, the party travelled across the ice and through very strong winds which were directly into their faces. On the 16th, after the wind stopped, he wrote:

It seems as if even sound has become frozen. The absolute calm strikes our ears making them ring. Not a buzz of insect, not even the note of the song bird but a silence awesome and spacelike. Nothing is comparable with the Antarctic Blizzard. Its awful winds and snow drifts \& yet in a calmer mood its quiet would drive one mad. We are now camped on the plateau. Ice boundless as the eye can discern on all sides. Around reigns a silence stagnant that seems worse than even noise. Yet what a welcome change to us, that have been so wind battered.

25 November. About noon two snow petrels came hovering around our camp and settled on the snow a few yards away. We hailed these wild creatures with joy for they are the only signs of living things we have seen for the past fortnight. From whence they came or whither bound gave us room for discussion.

Hurley writing in the tent:

16 December. It was hard to imagine we were on the plateau with nearly 250 miles of ice separating us from the hut. There was not even enough wind to stir the tent and although zero, it was warm. I thought it seemed as if camped in the Australian bush and was only brought back to Antarctica by the vigorous boiling of the cooker.

19 December. An absolute hush fell over the plateau, broken only by the creak \& groan of our sledge runners over the polished snow or our 
occasional comment on the heat. Bob remarked that it was quite like an Australian summer's day and we could really have partaken [of] ice cream with relish. ${ }^{10}$

As always, it is about people, as I noted in the beginning. Here's a wonderful exchange of sounds between people and penguins as recorded by Edward Wilson during his first Antarctic trip.

They have lost none of their attractiveness, and are most comical and interesting; as curious as ever, they will always come up at a trot when we sing to them, and you may often see a group of explorers on the poop singing 'For she's got bells on her fingers and rings on her toes, elephants to ride upon wherever she goes,' and so on at the top of their voices to an admiring group of Adélie penguins. Meares is the greatest attraction; he has a full voice which is musical but always very flat. He declares that 'God save the King' will always send them to the water, and certainly it is often successful. ${ }^{11}$

I finish with this lovely quote from Edgeworth David talking about watching the southern lights, the aurora australis.

Amundsen told me that when he was at Framheim at the east of Barrier Reef just before his famous dash to the Pole, he was called out of his winter quarters one very cold night by Johansen in order to hear what Johansen described as the crackling of the aurora australis. It was a very cold and still night. Amundsen distinctly heard a very faint rhythmically repeated rustling noise in the air. After a time he discovered that this was due to the rapid freezing of the moisture from his breath, and the tiny tinkle made by the minute crystals as they slowly descended under gravity close to his face, sufficiently close for the ear just to catch the faint sound ... He said that he was now confident that this was the true explanation of what poets call the 'crackling of the Northern Lights'. ${ }^{12}$

You won't always have your Antarctic noises beautifully framed by silence and sometimes they will be familiar and human or just plain weird but understandable, but when you do hear a sound coming through the intense silence that a place like Antarctica can engender then you'll realise that you've been in a new and special place in the world. It is a different and remarkable sensory experience, one with strong musical undertones.

10 Frank Hurley in Stephen Martin (1996) A history of Antarctica, pp. 147-8.

11 Edward Wilson in Stephen Martin (2009) Penguin, Reaktion Press, London, p. 35.

12 Edgeworth David in Martin (1996) op. cit. p. 24. 
This text is taken from Antarctica: Music, sounds and cultural connections, edited by Bernadette Hince, Rupert Summerson and Arnan Wiesel, published 2015 by ANU Press, The Australian National University, Canberra, Australia. 